BOTANICA

ISSN 2538-8657

2020, 26(1): 1-14

\title{
LIFE STAGES AND DEMOGRAPHY OF INVASIVE SHRUB CYTISUS SCOPARIUS (FABACEAE) IN LITHUANIA
}

\section{Laurynas TAURA, Zigmantas GudžINSKAs*}

Nature Research Centre, Institute of Botany, Žaliųų Ežerų Str. 49, 12200 Vilnius, Lithuania

"Corresponding author. E-mail: zigmantas.gudzinskas@gamtc.lt

\begin{abstract}
Taura L., Gudžinskas Z., 2020: Life stages and demography of invasive shrub Cytisus scoparius (Fabaceae) in Lithuania. - Botanica, 26(1): 1-14.

Alien invasive woody plant species, particularly those associated with nitrogen-fixing bacteria, are of special concern, because they may cause drastic changes in entire ecosystems. Although most of invasive species of Lithuania originate from other continents, one of these, Cytisus scoparius, is native to Europe. Fast spread of this species in Lithuania and its invasion to forest, coastal and continental sand, occasionally grassland habitats, stimulated us to study demographic structure of its populations. The aim of this research was to evaluate density, life stage and age structure of the populations, and to analyse relationships of the age of individuals with their life stages, height and stem diameter. Five populations were studied in the western, southern and eastern parts of Lithuania in July-August 2017. For the study, we selected stands of this species occupying at least 0.1 ha in a uniform habitat. We applied sampling plot method, and studied at least 100 individuals in each population, excluding seedlings. The age, life stage, height and stem diameter of 583 individuals were studied. The average density of individuals ranged between 5.15 individuals $/ \mathrm{m}^{2}$ and 15.40 individuals $/ \mathrm{m}^{2}$. Juvenile individuals reach the stage of vegetative adults on the second or third growth season, occasionally on the third year they reach even the stage of generative adults. The average age of juveniles was 1.10 years, of vegetative adults it was 2.99 years and 6.26 years of generative adults. The oldest generative individual was 28 years old. Linear regression analysis of the relationship between the plant age and the stem diameter revealed that the age predetermined the stem diameter variance by $81.0 \%$ in the studied populations. This study revealed that densities of C. scoparius individuals of all life stages in disturbed and undisturbed habitats were sufficient to sustain longevity and further expansion of populations. Therefore, appropriate measures for control and eradication of this species should be applied, particularly in the habitats of high conservation value.
\end{abstract}

Keywords: age, dendrochronology, generative adults, juveniles, population density, seedlings, vegetative adults.

\section{INTRODUCTION}

Alien invasive trees and shrubs, particularly those associated with nitrogen-fixing bacteria, are of special concern, because, in many situations, adding an extra biogeochemical function or a new vegetation layer may cause drastic changes in entire ecosystems (REJMÁNEK, 2014). Besides, during their quite long life cycle, trees and shrubs tend to produce substantial quantities of propagules and thus may occupy large areas (Dodet \& Collet, 2012). In Lithuania, 90 woody alien species have been recorded (GUDŽINSKAS et al., 2017; GUDŽINSKAS, 2018) and six of these have legally been recognized as invasive (GUDŽINSKAS \& ŽalnERAVIČIUS, 2017). Although most of invasive species of Lithuania originate from other continents, one of these, Cytisus scoparius, is native to Europe. This species, alongside with Robinia pseudoacacia, is associated with nitrogen-fixing bacteria and rises major concern because of its threat to continental and coastal habitats of the conservation value (GUDŽINSKAS \& ŽALNERAVIČIUS, 2016). 
Cytisus scoparius (L.) Link (Fabaceae) is native to Europe and North Africa. In Europe, the native range of this species lays within an area bounded to Spain and Portugal in the south-west, north to the British Isles, east to southern Sweden and the westcentral Ukraine and south to northern and central Italy (Frodin \& Heywood, 1968; Potter et al., 2009). In other areas of Europe, C. scoparius is considered as alien species (Frodin \& Heywood, 1968; Gavrilova \& Šulcs, 1999; Sarateanu et al., 2017). This species has been introduced and has become invasive in many regions of the world, including North America (PArker et al., 2002; Oneto et al., 2010; Muir \& VAMOSI, 2015), South America (IsAACSON, 2000; LeÓN Cordero et al., 2016), South Africa (Mkhize et al., 2013; Мватha, 2016), Asia (Suzuki, 2000; SRinivaSAN et al., 2011), Australia and New Zealand (WILLiams, 1981; Downey \& Smith, 2000; Sмith, 2000; TRAN et al., 2016).

In Lithuania, C. scoparius was introduced at the end of the 19th century (ABROMEIT et al., 1903; GUDŽINSKAS, 1999). In the second half of the 20th century, it was recommended for cultivation in fire protection belts of forests, for erosion control and as fodder plant for game animals, and then the rapid spread, naturalization and invasion of C. scoparius began. Currently, C. scoparius is a widespread shrub in western, southern and eastern Lithuania, however, it is rare or absent in the northern part of the country (STANCEVIČIUS, 1971; GuDŽINSKAS, 1999; GuDŽINSKAS et al., 2014). Considering the invasiveness and negative effect of $C$. scoparius on native species and habitats, it has been included into the List of Invasive Species of Lithuania (GUDžINSKAS \& ŽALNERAVIČIUS, 2016, 2017).

Studies on the life history, population structure and growth rate of invasive plant species provide important information about mechanisms of invasion and foresee control, management and eradication measures (SAKAI et al., 2001; RAmula et al., 2008). Population structure of $C$. scoparius has been widely studied in the regions, where this species is highly invasive (Downey \& SMith, 2000; SMith, 2000; PAynTER et al., 2003; SRINIVASAN et al., 2007) or its spread has just started, and further invasion is suspected (León Cordero et al., 2016; MBAtha, 2016). Quite a few studies on the population have been performed in Europe, in the native range of this species (PAYNTER et al., 2000, 2003).
Analyses of the age of C. scoparius individuals and its relationships with morphological characters have revealed that stem diameter is a better indicator of a plant age than its height (PAYNTER et al., 2003; SRINIVASAN et al., 2007). The oldest generative individual of C. scoparius in Australia has been recorded being 28 years old, in New Zealand it is 17 years old, in India 13 years old, whereas in the native range in France, the oldest registered individual is 16 years old (REES \& PAYNTER, 1997; PAYNTER et al., 2003; SRINIVASAN et al., 2007). Reported densities of individuals in different regions of the world vary in a broad range (from 0.06 individuals $/ \mathrm{m}^{2}$ to 21 individuals $/ \mathrm{m}^{2}$ ) depending on the type of habitat, the size of population and time of its establishment (DownEY \& SMith, 2000; Paynter et al., 2003; Srinivasan et al., 2007; Mbatha, 2016). PAynter et al. (2000) have found that in European populations beneath established stands of $C$. scoparius its recruitment is absent. They have concluded that $C$. scoparius is clearly adapted to exploit disturbances that eliminate native competing vegetation; however, in Australia, this species invades new habitats irrespective of large-scale disturbances (Downey \& SMith, 2000).

Fast spread of $C$. scoparius in Lithuania and its invasion to forest, coastal and continental sand, occasionally grassland habitats, stimulated us to study demographic structure of its populations and regularities of their development. The aim of this research was to answer the following questions: (a) what is the density of C. scoparius populations in Lithuania? (b) what is the life stage and the age structure of populations? (c) what are the relationships between the age of individuals and their life stages, plant height and stem diameter? The knowledge about population structure, growth rate and life history of invasive species is important in selecting measures to control and eradicate the population.

\section{MATERIALS AND METHODS}

\section{Study sites}

Five populations of $C$. scoparius were studied in the western, southern and eastern parts of Lithuania in July-August 2017 (Table 1, Fig. 1). We selected stands for the research of this species occupying substantial areas (at least 0.1 ha) in a uniform habitat.

Habitat types of C. scoparius study sites were identified and named after EUNIS Habitat Classifi- 


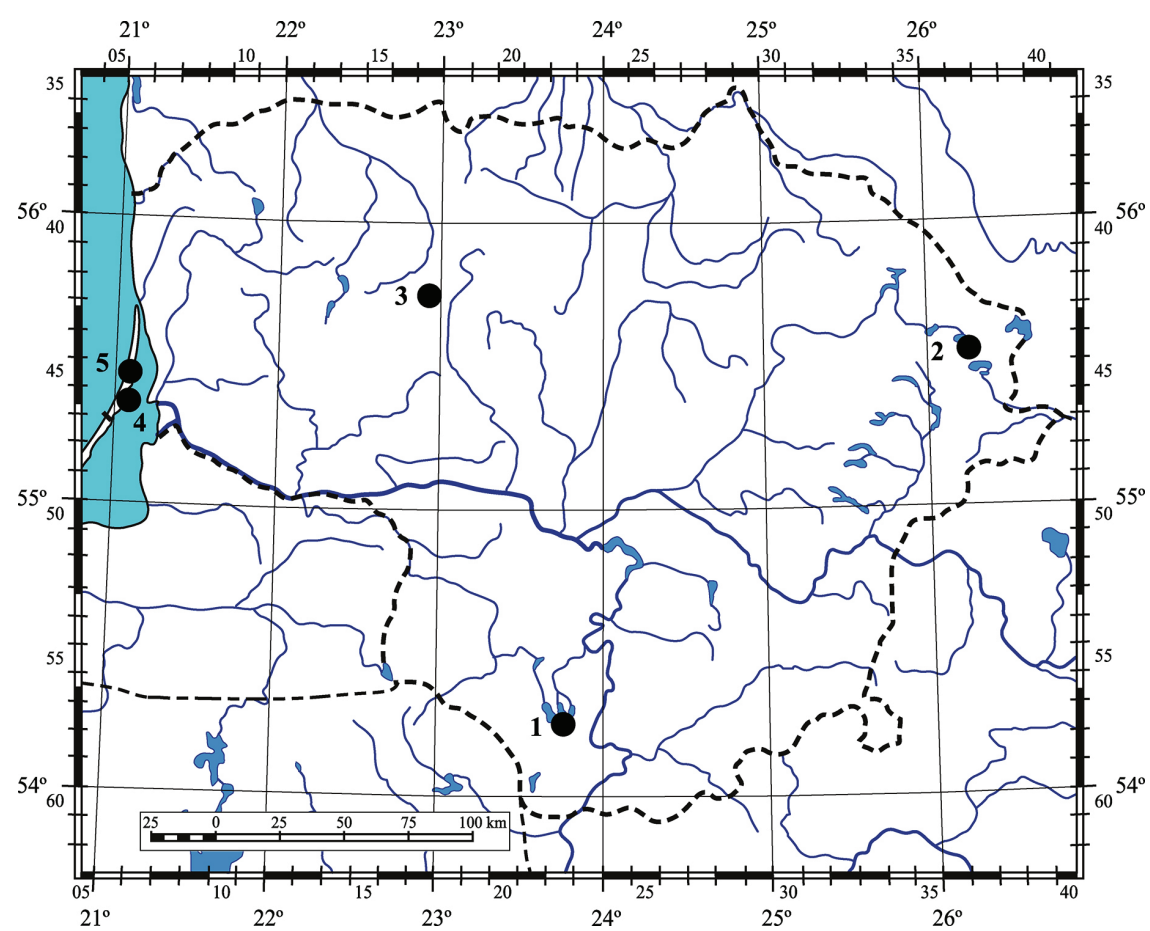

Fig. 1. Location of the study sites of Cytisus scoparius populations in Lithuania. Population numbers correspond with those presented in Table 1

Table 1. Geographic location of the study sites of Cytisus scoparius populations in Lithuania

\begin{tabular}{|c|l|l|c|c|}
\hline Population number & \multicolumn{1}{|c|}{ Site name } & \multicolumn{1}{c|}{ Administrative unit } & Longitude $\left({ }^{\circ} \mathrm{N}\right)$ & Latitude $\left({ }^{\circ} \mathrm{E}\right)$ \\
\hline 1 & Meteliai & Lazdijai district & 54.268984 & 23.752699 \\
\hline 2 & Didžiasalis & Ignalina district & 55.567031 & 26.269393 \\
\hline 3 & Galvydiške & Kelmė district & 55.786899 & 22.961950 \\
\hline 4 & Preila & Neringa city & 55.378373 & 21.038132 \\
\hline 5 & Nagliai & Neringa city & 55.463899 & 21.078483 \\
\hline
\end{tabular}

cation (DAVIES et al., 2004) with later corrections and amendments (European Environmental Agency, 2017). Three of the sampled populations of C. scoparius occurred in the subcontinental Scots pine forest (G3.421), one population in the Baltic dune Scots pine wood (G3.424) and one population in the northern fixed grey dune (B1.41) habitats (Table 2).

Tree layer in the habitats of subcontinental Scots pine forest (G3.421) was dominated by Pinus sylvestris and admixture of solitary Betula pendula. Similar structure of the tree stand was in the Baltic dune Scots pine wood (G3.424) habitat, but solitary individuals of Picea abies and Betula pubescens also occurred. In the habitat of northern fixed grey dunes (B1.41), shrub layer was composed of solitary young individuals of Pinus sylvestris, Juniperus communis and Salix rosmarinifolia. The herb layer in the habitat was dominated by Carex arenaria, Festuca psammophila, Hieracium umbellatum and Jasione montana.

\section{Sampling procedures}

The study on populations of Cytisus scoparius was conducted applying sampling plot method. At least 10 sampling plots were studied in each population to include at least 100 individuals of the study species, excluding seedlings. In individual populations, depending on the density of C. scoparius, from 10 to 20 sampling plots (Table 2) of $1 \mathrm{~m}^{2}$ in size and arranged in one transect were investigated. Sampling plots were delimited with wooden frame with sides of $1 \mathrm{~m}$. The first sampling plot of transect was selected at least $3 \mathrm{~m}$ from the edge of the stand in uniform community. 
Table 2. Habitat types, population size, number of sampling plots and cover of vegetation layers at the study sites of Cytisus scoparius populations

\begin{tabular}{|l|l|l|l|l|l|}
\hline Site name & Meteliai & Didžiasalis & Galvydiške & Preila & Nagliai \\
\hline Habitat type & G3.421 & G3.421 & G3.421 & G3.424 & B1.41 \\
\hline Population size (ha) & 0.15 & 2.00 & 0.23 & 0.75 & 0.35 \\
\hline Cover of Cytisus scoparius (\%) & 20 & 30 & 15 & 25 & 10 \\
\hline Cover of tree layer (\%) & 50 & 60 & 50 & 60 & 0 \\
\hline Cover of shrub layer (\%) & 30 & 40 & 30 & 40 & 15 \\
\hline Cover of herb layer (\%) & 40 & 30 & 40 & 30 & 60 \\
\hline Cover of bottom layer (\%) & 80 & 80 & 70 & 90 & 50 \\
\hline Bare soil (\%) & 3 & 0 & 20 & 0 & 20 \\
\hline Age of dominant trees (years) & 70 & 60 & 70 & 80 & - \\
\hline
\end{tabular}

The studied individuals of $C$. scoparius were divided into four life stage groups basing on their size and morphological characteristics. Plants grown from seeds in the study year and still having cotyledon leaves were treated as seedlings. Individuals with single unbranched or few-branched stem (with 1-3 lateral branches), densely hairy leaves and without cotyledon leaves were ascribed to the group of juveniles. Individuals with several branches and usually branched from the base of the stem, but without generative organs, were treated as vegetative adults. Individuals with at least one flower or fruit were ascribed to the group of generative adults.

The height of each C. scoparius individual occurring in sampling plots was measured with measuring type with accuracy of $1 \mathrm{~cm}$ and the diameter of its stem at the ground level was measured using electronic digital calliper (WZSL 150) with the accuracy of $0.01 \mathrm{~mm}$. Then each plant was uprooted and section of the stem (ca. $10 \mathrm{~cm}$ long) from the root neck was taken for dendrochronological analysis. All stem sections were numbered and placed into textile bags for drying. Stems prior to analysis were dried for at least two months under ambient conditions in a well aerated room.

\section{Age of individuals}

Age of individuals was assessed applying dendrochronological methods. Sections of ca. $2 \mathrm{~cm}$ were cut from each dried C. scoparius stem sample with a hand saw, whereas stems of thin individuals $(3 \mathrm{~mm}$ in diameter or less) were cut with scalpel. One surface of the section was polished with sandpaper. The polished surface of the samples was stained using vegetable oil boiled with Curcuma rhizome powder.
Prepared cross-sections of the stem were analysed using the binocular microscope (LEICA AZ4), and the number of annual rings in the xylem were counted.

\section{Statistical analyses}

The normality of data distribution was evaluated using the Shapiro-Wilk test. The results of descriptive statistics included average values and standard deviations (average $\pm \mathrm{SD}$ ), for plant height, stem diameter and absolute age of individuals, minimum and maximum values were given. Because the density of individuals in the sampling plots were distributed non-normally or different numbers of individuals of certain life stage or age group were recorded in the studied populations, comparisons of their densities, age structure, height and stem diameter were analysed by applying the non-parametric KruskalWallis $H$-test and the Mann-Whitney post-hoc pairwise comparisons. Relationships between the age of individuals (independent variable) and their height and stem diameter (dependent variables) were evaluated applying linear regression models. All calculations were performed using PAST 3.20 (Hammer et al., 2001).

\section{RESULTS}

\section{Density of individuals}

The density of generative adults of Cytisus scoparius in the studied populations ranged from $1.75 \pm$ 0.91 ind. $/ \mathrm{m}^{2}$ (Didžiasalis) to $3.07 \pm 1.53$ ind. $/ \mathrm{m}^{2}$ (Nagliai) (Table 3). Thus, the highest density of generative adults was in an open dune habitat, whereas the lowest density was in undisturbed pine forest. According to the results of the Kruskal-Wallis test, 
all populations differed significantly $(H=9.71$; $p=0.034$ ), however, the Mann-Whitney pairwise comparison revealed significant differences only between Didžiasalis and Preila $(U=59.5 ; p=0.013)$ and Didžiasalis and Nagliai $(U=51.0 ; p=0.004)$ populations.

The density of vegetative adults in the sampled populations was substantially variable and ranged from $1.88 \pm 1.54$ ind. $/ \mathrm{m}^{2}$ (Meteliai) to $7.60 \pm 8.16$ ind. $/ \mathrm{m}^{2}$ (Galvydiškè) (Table 3). The highest densities of vegetative adults were found in disturbed pine forest habitat and dune woodland habitat. The Kruskal-Wallis test revealed significant differences between all studied populations $(H=9.35$; $p=0.048)$. The Mann-Whitney pairwise comparison revealed significant differences between Meteliai and Galvydiškè $(U=38.5 ; p=0.025)$, Meteliai and Preila $(U=69.0 ; p=0.041)$, Meteliai and Nagliai $(U=62.0 ; p=0.019)$ and Didžiasalis and Galvydiške $(U=55.5 ; p=0.049)$ populations.

The density of juvenile individuals in the studied populations ranged from $0.06 \pm 0.26$ ind. $/ \mathrm{m}^{2}$ (Nagliai) to $5.50 \pm 5.79 \mathrm{ind} . / \mathrm{m}^{2}$ (Galvydiškè) (Table 3). The highest density of juveniles was recorded in disturbed ( $20 \%$ of the bottom layer surface) pine forest habitat, whereas the lowest density was in dune habitat. According to the results of the Kruskal-Wallis test, there were significant differences between populations $(H=13.25 ; p=0.001)$. The Mann-Whitney pairwise comparison revealed significant differences between most of populations (Table 3 ).

The density of all individuals irrespective of their life stage (seedlings excluded) in the studied populations ranged from $5.15 \pm 4.57 \mathrm{ind} . / \mathrm{m}^{2}$ (Didžiasalis) to $15.40 \pm 13.21 \mathrm{ind} . / \mathrm{m}^{2}$ (Galvydiškè). Thus, the highest density of individuals was in disturbed pine forest habitat, whereas the lowest density was in the same type, but undisturbed habitat. The results of the Kruskal-
Wallis test revealed significant differences between the sampled populations according to the density of individuals of pooled all life stage groups $(H=11.33$; $p=0.022$ ). However, by applying the Mann-Whitney pairwise comparison, significant differences were found between Didžiasalis and Galvydiškè ( $U=40.0$; $p=0.008)$, Preila $(U=83.0 ; p=0.026)$ and Nagliai $(U=87.5 ; p=0.037)$ populations.

The number of seedlings in the study plots was low (17 in Meteliai, two in Didžiasalis and one in Nagliai) and their density was $1.06 \pm 2.32 \mathrm{ind} . / \mathrm{m}^{2}(\mathrm{Me}-$ teliai), $0.10 \pm 0.30$ ind. $/ \mathrm{m}^{2}$ (Didžiasalis) and $0.06 \pm$ 0.26 ind. $/ \mathrm{m}^{2}$ (Nagliai). In Preila and Galvydiškè, no seedlings were recorded in the sampling plots.

\section{Age of individuals}

The average age of all studied generative adults $(n=187)$ was $6.26 \pm 2.74$ years. At the population level (Table 4), the average age of generative adults ranged from $5.11 \pm 1.62$ years (Preila) to $7.67 \pm 4.06$ years (Nagliai). The results of the Kruskal-Wallis test revealed statistically significant differences among populations $(H=21.93 ; p<0.001)$. Pairwise comparison by applying the Mann-Whitney test revealed that the population of Preila according to the age of individuals was statistically significantly different from those of Meteliai $(U=636.0 ; p=0.036)$, Didžiasalis $(U=485.0 ; p=0.006)$, Galvydiške $(U=305.5 ; p=0.009)$ and Nagliai $(U=462.5$; $p<0.001)$. Besides, statistically significant difference was found between Meteliai and Nagliai populations $(U=608.5 ; p=0.006)$.

The average age of all vegetative adults studied $(n=280)$ was $2.99 \pm 0.92$ years (Table 4$)$. At the population level, the average age of vegetative adults ranged from $2.43 \pm 0.73$ years (Galvydiškè) to $3.37 \pm 0.93$ years (Meteliai). The Kruskal-Wallis test showed statistically significant differences

Table 3. Density (average $\pm \mathrm{SD}$ ) of Cytisus scoparius individuals (individuals $/ \mathrm{m}^{2}$ ) by the life stage groups in the studied populations ( $n$-the number of studied individuals). The same letter denotes statistically significant differences between populations by applying the Mann-Whitney pairwise comparison

\begin{tabular}{|l|c|c|c|c|c|c|}
\hline Site name & Number of sampling plots & $n$ & Generative adults & Vegetative adults & Juveniles & All groups \\
\hline Meteliai & 16 & 105 & $2.50 \pm 1.71$ & $1.88 \pm 1.54^{\text {abc }}$ & $2.19 \pm 2.28^{\text {abc }}$ & $6.56 \pm 2.89$ \\
\hline Didžiasalis & 20 & 103 & $1.75 \pm 0.91^{\mathrm{ab}}$ & $2.70 \pm 3.25^{\mathrm{d}}$ & $0.70 \pm 1.69^{\mathrm{ad}}$ & $5.15 \pm 4.57^{\mathrm{abc}}$ \\
\hline Galvydiškè & 10 & 154 & $2.30 \pm 0.95$ & $7.60 \pm 8.16^{\text {ad }}$ & $5.50 \pm 5.79^{\text {def }}$ & $15.40 \pm 13.21^{\mathrm{a}}$ \\
\hline Preila & 15 & 116 & $2.87 \pm 1.51^{\mathrm{a}}$ & $4.33 \pm 4.25^{\mathrm{b}}$ & $0.53 \pm 0.83^{\text {be }}$ & $7.73 \pm 4.22^{\mathrm{b}}$ \\
\hline Nagliai & 15 & 102 & $3.07 \pm 1.53^{\mathrm{b}}$ & $3.67 \pm 2.94^{\mathrm{c}}$ & $0.06 \pm 0.26^{\mathrm{cf}}$ & $6.80 \pm 2.78^{\mathrm{c}}$ \\
\hline
\end{tabular}


among populations $(H=44.07 ; p<0.001)$. Pairwise comparison by applying the Mann-Whitney test revealed that according to the age of vegetative adults, only the population of Galvydiškè was statistically significantly different from Meteliai $(U=476.5$; $p<0.001$ ), Didžiasalis $(U=1136.0 ; p<0.001)$, Preila $(U=1008.0 ; p<0.001)$ and Nagliai $(U=1314.1$; $p<0.001)$.

The average age of juveniles in all studied populations pooled $(\mathrm{n}=116)$ was $1.10 \pm 0.30$ years and variation of the average age among populations was low (Table 4). The Kruskal-Wallis test $(H=0.15$; $p<0.889$ ) and the pairwise comparison revealed no statistically significant differences among and between populations according to the age of juveniles.

Analysis of the age of all individuals pooled ( $\mathrm{n}=583$, excluding seedlings) of all studied populations showed that fractions of one- to three-year-old plants were almost equal and comprised from $18.0 \%$ to $19.2 \%$ (Fig. 2). Fraction of four-year-old and older individuals gradually decreased and ten-year-old individuals and older comprised only $2.2 \%$. Thus, the results suggested that mortality of generative adults was quite high and population stability was ensured by constant recruitment.

Analysis of the age of individuals by life stage groups in pooled data of all studied C. scoparius populations also revealed important regularities. Individuals of this species occasionally reached the generative stage being three years old, though they comprised a small fraction (six individuals or $3.2 \%$ ) of all generative individuals $(n=187)$ or $5.4 \%$ of all three-year-old individuals $(n=112)$. The largest fraction $(63.6 \%)$ of generative adults comprised individuals aged four years (35 or $18.7 \%$ ), five years (49 or $26.2 \%$ ) and six years (35 or $18.7 \%$ ). Older individuals were less frequent in all populations and their fraction with the age decreased among generative adults. Individuals aged seven years (19 or $10.2 \%$ ), eight years (21 or $11.2 \%$ ) and nine years (9 or $4.8 \%$ ) altogether comprised $26.2 \%$. Ten and more years old individuals were quite rare and comprised 7.0\% (13 individuals) of all generative adults. It should be noted that the oldest $C$. scoparius individual in the study plots was 28 years old and it was recorded in Nagliai population.

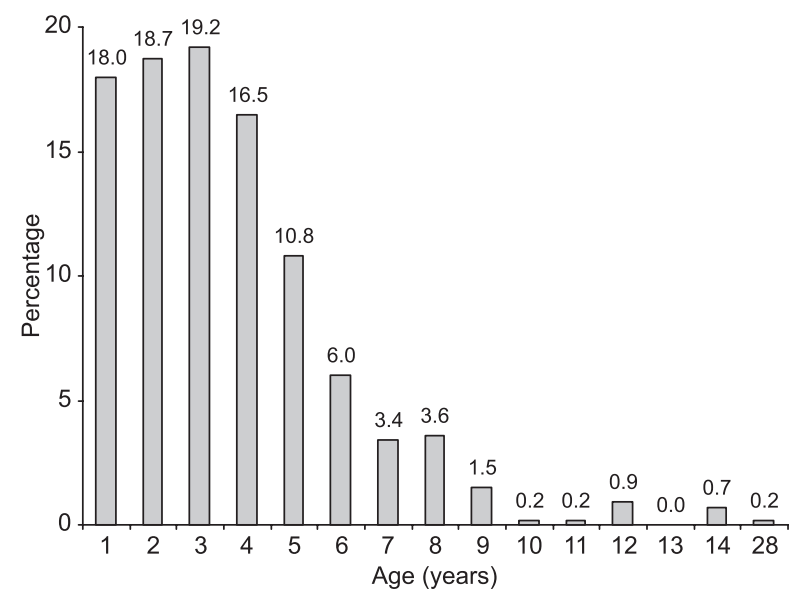

Fig. 2. Distribution of Cytisus scoparius individuals $(n=583)$, excluding seedlings, according to the age in all populations

Table 4. The age (years, average \pm SD, minimum and maximum values) of Cytisus scoparius individuals estimated by life stages in the studied populations and the number of studied individuals $(n)$. The same letter denotes statistically significant differences between populations within the same life stage group by applying the Mann-Whitney pairwise comparison

\begin{tabular}{|c|c|c|c|c|c|c|}
\hline \multirow[b]{2}{*}{ Site name } & \multicolumn{2}{|c|}{ Generative adults } & \multicolumn{2}{|c|}{ Vegetative adults } & \multicolumn{2}{|r|}{ Juveniles } \\
\hline & $n$ & $\begin{array}{c}\text { average } \pm \text { SD } \\
\text { min-max (years) }\end{array}$ & $\mathrm{n}$ & $\begin{array}{c}\text { average } \pm \text { SD } \\
\text { min-max (years) }\end{array}$ & $\mathrm{n}$ & $\begin{array}{c}\text { average } \pm \text { SD } \\
\text { min-max (years) }\end{array}$ \\
\hline Meteliai & 40 & $\begin{array}{c}5.78 \pm 1.64^{\mathrm{ab}} \\
4-11\end{array}$ & 30 & $\begin{array}{c}3.37 \pm 0.93^{\mathrm{a}} \\
2-5\end{array}$ & 35 & $\begin{array}{c}1.11 \pm 0.32 \\
1-2\end{array}$ \\
\hline Didžiasalis & 35 & $\begin{array}{c}6.46 \pm 2.59^{c} \\
3-14\end{array}$ & 54 & $\begin{array}{c}3.13 \pm 0.97^{\mathrm{b}} \\
2-7\end{array}$ & 14 & $\begin{array}{c}1.07 \pm 0.27 \\
1-2\end{array}$ \\
\hline Galvydiškè & 23 & $\begin{array}{c}6.13 \pm 1.57^{\mathrm{d}} \\
3-9\end{array}$ & 63 & $\begin{array}{c}2.43 \pm 0.73^{\mathrm{abcd}} \\
2-4\end{array}$ & 58 & $\begin{array}{c}1.07 \pm 0.26 \\
1-2\end{array}$ \\
\hline Preila & 43 & $\begin{array}{c}5.11 \pm 1.62^{\text {acde }} \\
3-10\end{array}$ & 65 & $\begin{array}{c}3.28 \pm 0.72^{\mathrm{c}} \\
2-5\end{array}$ & 8 & $\begin{array}{c}1.13 \pm 0.35 \\
1-2\end{array}$ \\
\hline Nagliai & 46 & $\begin{array}{c}7.67 \pm 4.06^{\text {be }} \\
4-28\end{array}$ & 55 & $\begin{array}{c}3.05 \pm 0.97^{\mathrm{d}} \\
2-5\end{array}$ & 1 & $\begin{array}{c}- \\
1-1\end{array}$ \\
\hline $\begin{array}{l}\text { All populations } \\
\text { pooled }\end{array}$ & 187 & $\begin{array}{c}6.26 \pm 2.74 \\
3-28\end{array}$ & 280 & $\begin{array}{c}2.99 \pm 0.92 \\
2-7\end{array}$ & 116 & $\begin{array}{c}1.10 \pm 0.30 \\
1-2\end{array}$ \\
\hline
\end{tabular}


Cytisus scoparius reach the stage of vegetative adults being two years old. The largest part of the studied vegetative adults $(n=280)$ were from two to four years old (265 individuals or 94.6\%). Two-year-old individuals (98) comprised $35.0 \%$, three-year-old individuals (106) comprised $37.9 \%$ and four-year-old individuals (61) comprised $21.8 \%$ of all vegetative adults. A few individuals belonged to the group of vegetative adults being five years old (14 individuals or 5.0\%) and one individual $(0.4 \%)$ was seven years old.

Most of individuals attributed to the group of juveniles were one year old (105 individuals) and comprised $90.5 \%$ of all individuals of this group ( $n=116)$. Two-year-old plants (11 individuals) comprised $9.5 \%$ of all juveniles.

\section{Height of individuals}

Linear regression analysis (Fig. 3) of the relationship between the plant height and its age, including vegetative and generative adults, revealed that the age predetermined the height variance by $47.4 \%$ in the studied populations $\left(r^{2}=0.474 ; p<0.001\right)$.

The height of generative adults of $C$. scoparius was a variable character within and among populations. The smallest generative adult was $32 \mathrm{~cm}$ tall (Didžiasalis), whereas the tallest plant was $247 \mathrm{~cm}$ (Preila). The average height of pooled all generative adults was $102.73 \pm 43.92 \mathrm{~cm}$ (Table 5). The average height of generative adults in individual studied populations ranged from $68.40 \pm 26.89 \mathrm{~cm}$ (Meteliai) to $131.04 \pm 29.46 \mathrm{~cm}$ (Galvydiškè).
The Kruskal-Wallis test revealed statistically significant differences of the height of generative adults among populations $(H=71.04 ; p<0.001)$. The Mann-Whitney test revealed that according to the height of generative adults, the population of Meteliai was statistically significantly different from all populations ( $p<0.001)$, and Didžiasalis was significantly different from Galvydiškè $(U=79.5 ; p<0.001)$, Preila $(U=345.5 ; p<0.001)$ and Nagliai $(U=403.5 ; p<0.001)$.

The height of vegetative adults of $C$. scoparius in the studied populations ranged from $12 \mathrm{~cm}$ (Nagliai) to $103 \mathrm{~cm}$ (Preila). The average height of all vegetative adults pooled was $44.18 \pm 23.30 \mathrm{~cm}$ (Table 5). The average height of vegetative adults in individual populations studied ranged from $35.43 \pm 20.29 \mathrm{~cm}$ (Galvydiškè) to $66.11 \pm 23.58 \mathrm{~cm}$ (Preila).

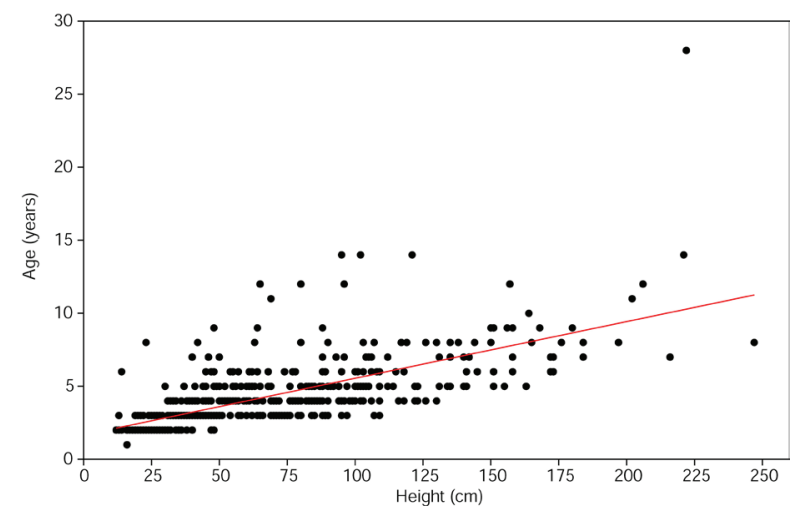

Fig. 3. Linear regression analysis of the relationship between the plant age and its height of the pooled vegetative and generative adult individuals of Cytisus scoparius $(\mathrm{n}=466)$ of the studied populations $\left(r^{2}=0.474 ; p<0.001\right)$

Table 5. Height (average \pm SD, minimum and maximum values) of Cytisus scoparius individuals estimated by the life stage groups in the studied populations and the number of studied individuals $(n)$. The same letter denotes statistically significant differences between populations within the same life stage group by applying the Mann-Whitney pairwise comparison

\begin{tabular}{|c|c|c|c|c|c|c|}
\hline \multirow[b]{2}{*}{ Site name } & \multicolumn{2}{|c|}{ Generative adults } & \multicolumn{2}{|c|}{ Vegetative adults } & \multicolumn{2}{|c|}{ Juveniles } \\
\hline & $n$ & $\begin{array}{l}\text { average } \pm \text { SD } \\
\min -\max (\mathrm{cm})\end{array}$ & $n$ & $\begin{array}{l}\text { average } \pm \text { SD } \\
\min -\max (\mathrm{cm})\end{array}$ & $n$ & $\begin{array}{l}\text { average } \pm \text { SD } \\
\min -\max (\mathrm{cm})\end{array}$ \\
\hline Meteliai & 40 & $\begin{array}{c}68.40 \pm 26.89^{\mathrm{a}} \\
36-155 \\
\end{array}$ & 30 & $\begin{array}{c}36.77 \pm 11.15^{\text {ab }} \\
20-56\end{array}$ & 35 & $\begin{array}{c}9.00 \pm 2.20^{\mathrm{a}} \\
5-14 \\
\end{array}$ \\
\hline Didžiasalis & 35 & $\begin{array}{c}83.40 \pm 27.71^{b} \\
32-141\end{array}$ & 54 & $\begin{array}{c}37.07 \pm 12.66^{\mathrm{ac}} \\
13-63\end{array}$ & 14 & $\begin{array}{c}11.43 \pm 2.14^{\mathrm{abc}} \\
7-15\end{array}$ \\
\hline Galvydiškè & 23 & $\begin{array}{c}131.04 \pm 29.46^{\mathrm{c}} \\
63-173\end{array}$ & 63 & $\begin{array}{c}35.43 \pm 20.29^{\text {bcdef }} \\
17-99\end{array}$ & 58 & $\begin{array}{c}9.25 \pm 2.48^{\mathrm{bd}} \\
5-17\end{array}$ \\
\hline Preila & 43 & $\begin{array}{c}117.67 \pm 41.67^{\mathrm{abcd}} \\
47-247\end{array}$ & 65 & $\begin{array}{c}66.11 \pm 23.58^{\mathrm{de}} \\
14-103\end{array}$ & 8 & $\begin{array}{c}7.38 \pm 2.72^{\mathrm{cd}} \\
5-12\end{array}$ \\
\hline Nagliai & 46 & $\begin{array}{c}122.61 \pm 46.91^{\mathrm{d}} \\
41-222\end{array}$ & 55 & $\begin{array}{c}44.07 \pm 23.51^{\mathrm{f}} \\
12-95\end{array}$ & 1 & $\frac{-}{10-10}$ \\
\hline $\begin{array}{l}\text { All populations } \\
\text { pooled }\end{array}$ & 187 & $\begin{array}{c}102.73 \pm 43.92 \\
32-247\end{array}$ & 280 & $\begin{array}{c}44.18 \pm 23.30 \\
12-103\end{array}$ & 116 & $\begin{array}{c}9.32 \pm 2.51 \\
5-17\end{array}$ \\
\hline
\end{tabular}


The results of the Kruskal-Wallis test revealed statistically significant differences between populations by the height of vegetative adults $(H=67.65$; $p<0.001)$. The Mann-Whitney test showed that according to the height of vegetative adults, the population of Meteliai was statistically significantly different from Galvydiškè $(U=842.0 ; p=0.037)$ and Preila $(U=289.0 ; p<0.001)$ populations. The population of Preila also statistically significantly differed from Didžiasalis $(U=489.5 ; p<0.001)$, Galvydiškè $(U=814.0 ; p<0.001)$ and Nagliai $(U=890.0$; $p<0.001)$.

The height of juveniles was quite constant and ranged from 5 to $17 \mathrm{~cm}$. The average height of all juveniles pooled was $9.32 \pm 2.51 \mathrm{~cm}$ (Table 5). The average height of juveniles in individual studied populations ranged from $7.38 \pm 2.72 \mathrm{~cm}$ (Preila) to $11.43 \pm$ $2.14 \mathrm{~cm}$ (Didžiasalis). According to the results of the Kruskal-Wallis test, statistically significant differences were found between populations by the height of juveniles $(H=15.1 ; p=0.002)$. The Mann-Whitney test revealed statistically significant differences between Didžiasalis and Meteliai $(U=106.0 ; p=0.002)$, Galvydiškè $(U=184.5 ; p=0.003)$ and Preila $(U=15.0$; $p=0.005)$ as well as between Galvydiškè and Preila $(U=124.0 ; p=0.047)$ populations.

\section{Stem diameter of individuals}

We found strong relationship between the plant age and the stem diameter. Linear regression analysis of all vegetative and generative adults $(n=466)$ showed (Fig. 4) that the age predetermined the stem diameter variation by $81.0 \%\left(r^{2}=0.810 ; p<0.001\right)$.

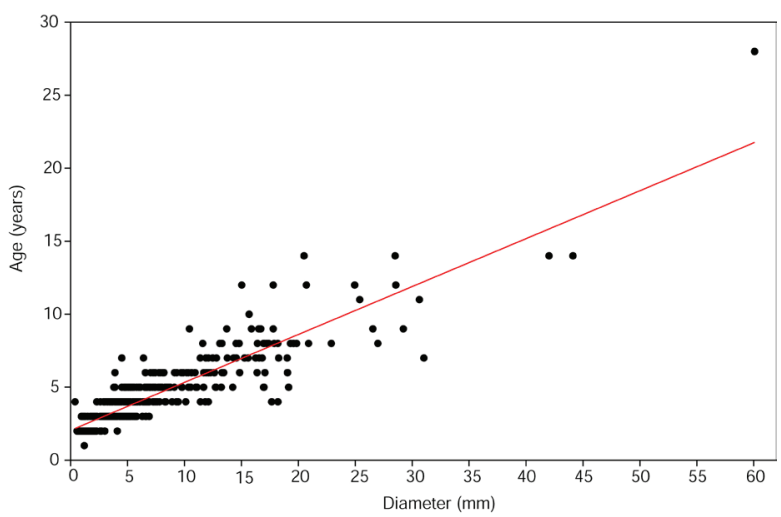

Fig. 4. Linear regression analysis of the relationship between the plant age and its stem diameter of pooled adult vegetative and generative individuals of Cytisus scoparius $(\mathrm{n}=466)$ of the populations studied $\left(r^{2}=0.810 ; p<0.001\right)$
The stem diameter of generative adults of C. scoparius varied in a broad range between individuals. The smallest stem diameter of generative adult was $1.39 \mathrm{~mm}$ (Preila), whereas the largest recorded stem diameter was $60.07 \mathrm{~mm}$ (Nagliai). The average stem diameter of all generative adults pooled was $12.92 \pm 7.56 \mathrm{~mm}$ (Table 6). The average stem diameter of generative adults in individual populations studied ranged from $8.77 \pm 3.92 \mathrm{~mm}$ (Meteliai) to $15.88 \pm 11.54 \mathrm{~mm}$ (Nagliai).

The Kruskal-Wallis test revealed statistically significant differences of the stem diameter of generative adults between populations $(H=19.07$; $p<0.001)$. The Mann-Whitney test showed that according to the stem diameter of generative adults, the population of Preila was statistically significantly different from all populations, i.e. from Meteliai $(U=508.5 ; p=0.001)$, Didžiasalis $(U=482.0$; $p=0.006)$, Galvydiškè $(U=237.0 ; p<0.001)$ and Nagliai $(U=560.0 ; p<0.001)$.

The stem diameter of vegetative adults ranged from $0.70 \mathrm{~mm}$ (Didžiasalis and Preila) to $8.91 \mathrm{~mm}$ (Nagliai). The average stem diameter of all vegetative adults pooled was $3.11 \pm 1.92 \mathrm{~mm}$ (Table 6 ). The average stem diameter of vegetative adults in individual studied populations ranged from $1.59 \pm 1.30 \mathrm{~mm}$ (Galvydiškè) to $4.07 \pm 1.68 \mathrm{~mm}$ (Meteliai).

The Kruskal-Wallis test revealed statistically significant differences of the stem diameter of vegetative adults between populations $(H=87.78$; $p<0.001)$. The Mann-Whitney pairwise comparison revealed that the population of Galvydiške was statistically significantly different from all populations according to the stem diameter of vegetative adults $(p<0.001)$. Besides, statistically significant differences were found between Didžiasalis and Meteliai $(U=571.5 ; p=0.026)$ as well as Didžiasalis and Preila $(U=1301.0 ; p=0.016)$.

The stem diameter of juveniles, like other characters of plants in this life stage group, was quite constant and ranged from $0.24 \mathrm{~mm}$ (Galvydiškè) to $1.16 \mathrm{~mm}$ (Meteliai). The average stem diameter of all juveniles pooled was $0.57 \pm 0.19 \mathrm{~mm}$ (Table 6). The average stem diameter of juveniles in individual studied populations ranged from $0.52 \pm 0.16 \mathrm{~mm}$ (Galvydiškè) to $0.69 \pm 0.20 \mathrm{~mm}$ (Didžiasalis).

According to the Kruskal-Wallis test, all populations studied statistically significantly differed by 
Table 6. Stem diameter (mm, average \pm SD, minimum and maximum values) of Cytisus scoparius individuals estimated by the life stage groups in the studied populations and the number of studied individuals $(n)$. The same letter denotes statistically significant differences between populations within the same life stage group by applying the Mann-Whitney pairwise comparison

\begin{tabular}{|c|c|c|c|c|c|c|}
\hline \multirow[b]{2}{*}{ Site name } & \multicolumn{2}{|c|}{ Generative adults } & \multicolumn{2}{|c|}{ Vegetative adults } & \multicolumn{2}{|c|}{ Juveniles } \\
\hline & $n$ & $\begin{array}{l}\text { average } \pm \text { SD } \\
\min -\max (\mathrm{mm})\end{array}$ & $n$ & $\begin{array}{l}\text { average } \pm \text { SD } \\
\min -\max (\mathrm{mm})\end{array}$ & $n$ & $\begin{array}{l}\text { average } \pm \text { SD } \\
\min -\max (\mathrm{mm})\end{array}$ \\
\hline Meteliai & 40 & $\begin{array}{c}12.79 \pm 5.96^{\mathrm{abcd}} \\
4.74-31.03\end{array}$ & 30 & $\begin{array}{c}4.07 \pm 1.68^{\mathrm{ab}} \\
1.18-7.85\end{array}$ & 35 & $\begin{array}{c}0.60 \pm 0.21 \\
0.27-1.16\end{array}$ \\
\hline Didžiasalis & 35 & $\begin{array}{c}11.73 \pm 5.37^{\text {aefg }} \\
3.50-28.50 \\
\end{array}$ & 54 & $\begin{array}{c}3.21 \pm 1.62^{\mathrm{c}} \\
0.70-6.90\end{array}$ & 14 & $\begin{array}{c}0.69 \pm 0.20^{\mathrm{a}} \\
0.30-1.00\end{array}$ \\
\hline Galvydiškè & 23 & $\begin{array}{c}12.82 \pm 4.51^{\text {be }} \\
5.46-22.90\end{array}$ & 63 & $\begin{array}{c}1.59 \pm 1.30^{\text {ad }} \\
0.60-6.54\end{array}$ & 58 & $\begin{array}{c}0.52 \pm 0.16^{\mathrm{a}} \\
0.24-0.98\end{array}$ \\
\hline Preila & 43 & $\begin{array}{c}8.77 \pm 3.92^{\mathrm{cf}} \\
1.39-19.56 \\
\end{array}$ & 65 & $\begin{array}{c}3.95 \pm 1.67^{\text {bcde }} \\
0.70-7.86\end{array}$ & 8 & $\begin{array}{c}0.54 \pm 0.14 \\
0.30-0.73\end{array}$ \\
\hline Nagliai & 46 & $\begin{array}{c}15.88 \pm 11.54^{\mathrm{dg}} \\
3.90-60.07\end{array}$ & 55 & $\begin{array}{c}3.63 \pm 2.11^{\mathrm{e}} \\
0.93-8.91 \\
\end{array}$ & 1 & $\frac{-}{0.90-0.90}$ \\
\hline $\begin{array}{l}\text { All populations } \\
\text { pooled }\end{array}$ & 187 & $\begin{array}{c}12.92 \pm 7.56 \\
1.39-60.07\end{array}$ & 280 & $\begin{array}{c}3.11 \pm 1.92 \\
0.56-8.91\end{array}$ & 116 & $\begin{array}{c}0.57 \pm 0.19 \\
0.24-1.16\end{array}$ \\
\hline
\end{tabular}

the stem diameter of juveniles $(H=8.58 ; p=0.035)$, however, the Mann-Whitney test revealed that significant difference was between Galvydiške and Didžiasalis $(U=199.0 ; p=0.006)$ population.

\section{DISCUSSION}

\section{Density of individuals}

Studies on the density of $C$. scoparius individuals in Europe, Australia, India, New Zealand and South Africa (Paynter et al., 2003; SRinivasan et al., 2007; Мватна, 2016) have revealed significant variations within and between study regions. In South Africa, the average density of individuals in the populations studied ranges from 0.06 ind. $/ \mathrm{m}^{2}$ to $9.5 \mathrm{ind} . / \mathrm{m}^{2}$ (Мватна, 2016). The average density of individuals in the populations studied in the native range of this species, in France and Spain, is 21 ind. $/ \mathrm{m}^{2}$, in Australia 25 ind. $/ \mathrm{m}^{2}$ and in New Zealand 6 ind. $/ \mathrm{m}^{2}$ (PAYNTER et al., 2003). Thus, in our studied populations, the average densities of individuals were lower than in invasive range in Australia and in the native range in Europe, but comparable with invasive populations in New Zealand and South Africa. The average density of individuals in Galvydiške population, occurring in pine forest with disturbed bottom layer and bare soil (about $20 \%$ of the surface) was significantly higher than in other populations studied (Table 2). PAYNTER et al. (2000) have concluded that C. scoparius is clearly adapted to exploit disturbances that eliminate native competing plant species; however, our study revealed that soil disturbances facilitate recruitment. Therefore, the highest density of juveniles and vegetative adults in Galvydiške population was found (Table 3). In contrast, the studies performed in Australia have revealed that $C$. scoparius invades new habitats irrespective of large-scale disturbances (Downey, SMITH, 2000).

PAYNTER et al. (2000) have found that in European populations beneath established stands of C. Scoparius its recruitment is absent. We registered the recruitment of $C$. scoparius from seeds in all populations, although its intensity was different. At undisturbed sites, the densities of juveniles were similar, whereas in populations with disturbed soil (Meteliai and Galvydiškè) it was significantly higher, whereas differences of the density of generative adults were insignificant (Table 3). Furthermore, the presence of undisturbed, naturally bare sand in dune habitat (Nagliai) had no effect on the recruitment. Thus, we presume that in Lithuania the spread and intense recruitment of C. scoparius is facilitated by habitat disturbances, particularly by the machinery for tree logging and forest maintenance in pine forest habitats and recreational activities in dune habitats.

\section{Age of individuals}

Dendrochronological analysis is a tool that enables to establish the age of woody plants precisely (CEDRO et al., 2013; ReHSCHUH et al., 2017). By applying the methods of dendrochronology, it is possible to reveal regularities or woody plant radial increment, longevity of an individual, effect of meteorological conditions 
and, in the case of invasive species, time of population establishment and intensity of recruitment (PAYNTER et al., 2003; SRINIVASAn et al., 2007; Mestre et al., 2014; RoJAs-BADILLA et al., 2017; GudŽInsKAs et al., 2020). Maximum reported lifespan of C. scoparius is 28 years in Australia, 21 years in New Zealand, 16 years in France and 13 years in India (Rees \& PAynter, 1997; Paynter et al., 2003; Srinivasan et al., 2007). The oldest individual of $C$. scoparius recorded during our study was 28 years old occurring in grey dune habitats at Nagliai site (Curonian Spit).

We analysed the age of individuals in life stage groups and revealed that juvenile stage of C. scoparius in Lithuania continues one or two growth seasons (Table 4). On the second or third growth season, the survived individuals reach the stage of vegetative adults, occasionally on the third year they reach even the stage of generative adults. The life stage of vegetative adults, depending on habitat conditions, density of individuals and other factors, continues usually until the end of the fourth growth season. Occasionally, solitary individuals of vegetative adult stage can be found being five to seven years old. We suppose that at least some older individuals of vegetative adult life stage might be damaged in previous years and re-sprouted. The largest part of generative adults in the studied populations comprises plants aged from four to six years (Table 4).

We found that individuals aged from one to three years comprise similar percentage and the fraction of individuals starting with four years gradually decreases and individuals of ten or more years comprise only small fraction of all individuals in populations (Fig. 2). This phenomenon could be explained either by high mortality of adult individuals because of diseases or meteorological factors (PAYNTER et al., 2003) or by the age of population establishment. As we do not know exact time of the studied population establishment, we cannot confirm or reject this presumption. However, existence of 28-year-old individual in Nagliai population and the absence of individuals aged from 15 years to 27 years support our presumption about the high mortality of generative individuals aged above 10 years.

\section{Height of individuals}

Considering the information provided by different sources, the height of generative adults of
C. scoparius is a variable feature and, in most cases, only maximum values have been reported. To our knowledge, the tallest individual of $C$. scoparius $(670 \mathrm{~cm})$ has been recorded in New South Wales, Australia (Downey \& SMith, 2000). The tallest individual in Europe has been recorded in Spain, $518 \mathrm{~cm}$ high (PAynter et al., 2003). The height of generative adults in South Africa has been established between $110 \mathrm{~cm}$ and $560 \mathrm{~cm}$ (МватнA, 2016), in India up to $300 \mathrm{~cm}$ (SRinivasan et al., 2007). The study on C. scoparius in Brazil has revealed that the average height of generative adults across populations range from $220 \mathrm{~cm}$ to $260 \mathrm{~cm}$ (LEÓN CORDERO et al., 2016). However, information on the variation in height of vegetative adults and juveniles from the native and invasive range is insufficient.

According to the results of the linear regression analysis (Fig. 3) of the relationship between the plant age height and its height, including vegetative and generative adults, we found that the age predetermined the height variance by $47.4 \%$. The analysis of relationships between the plant age and height based on Indian populations (SRINIVASAN et al., 2007) has revealed that the age predetermined the height variance by $39.0 \%$. Significantly higher values have been presented by PAYNTER et al. (2003) basing on the study of populations from Europe, Australia and New Zealand. They have found that the plant age predetermined the height variance by $66.0 \%$. Such results suggest that the increase in height of C. scoparius individuals is not always continuous.

We found that generative adults of $C$. scoparius in the studied populations were significantly smaller than maximum values recorded in Australia and South Africa (Downey \& Smith, 2000; МватнA, 2016), but comparable with those recorded in Brazil (León Cordero et al., 2016). The highest recorded individual during this study in Lithuania was $247 \mathrm{~cm}$ high. The maximum average plant height at the population level was registered in pine forest habitat in Galvydiškè and in dune habitat in Nagliai. The population in dune pine wood habitat in Preila occupied intermediate position, which was statistically significantly different from all studied populations (Table 5). Although the cover of all vegetation layers in Preila was almost the same as in Didžiasalis habitat (Table 2), the height of generative adults at the latter site was statistically significantly lower than in 
Preila (Table 5). Thus, the height of generative adults in these habitats probably was determined by other factors than light availability. The smallest recorded generative adult was $36 \mathrm{~cm}$ high.

The height of vegetative adults in the studied populations varied in a broad range within and among populations. The smallest individual ascribed to this life stage group was $12 \mathrm{~cm}$ high, whereas the tallest individual was $103 \mathrm{~cm}$ high (Table 5). The maximum average height of vegetative adults was in dune pine wood habitat in Preila, but not in an open dune habitat in Nagliai, as it might be expected. Therefore, we can presume that $C$. scoparius, at least in the boreal biogeographical region of Europe, is a shade tolerant and is able to invade forest habitats with quite high (ca. 60\%) cover of the tree layers and moderate shrub layer (Table 2). The height of juveniles varied in a narrow range and the tallest juvenile was $17 \mathrm{~cm}$ high. Thus, the height of individuals ascribed to the groups of juvenile, vegetative adult and generative adult life stage overlap and the height alone cannot be used as a single criterion for the segregation of $C$. scoparius life stages.

\section{Stem diameter of individuals}

Information on the variation in stem diameter of C. scoparius both in the native and invasive ranges is quite scarce. It has been reported that in South African populations stem diameter of generative adults' ranges between 19 and $157 \mathrm{~mm}$ (Мватна, 2016). Although stem diameter has been studied in the populations in Europe, Australia, New Zealand and India (PAynter et al., 2003; Srinivasan et al., 2007), no results are reported for the determined values.

We found strong relationship between the plant ages and stem diameter. Linear regression analysis of all vegetative and generative adults showed (Fig. 4) that the plant age predetermined the stem diameter variance by $81.0 \%$. PAYNTER et al. (2003) have found that the age predetermined the stem diameter variance by $88.0 \%$. Our findings are comparable with the results of PAYNTER et al. (2003), but both differ significantly from the results of the study on Indian populations, where the age of individuals predetermined the stem diameter variance only by $47.0 \%$ (SRINIVASAN et al., 2007). Thus, in populations included in our study as well as those analysed by PAYNTER et al. (2003), the radial increment of the stem diameter of
C. scoparius is quite uniform between vegetative and generative adults.

Stem diameter of generative adults in the studied populations in Lithuania varied in a broad range (Table 6). The largest average stem diameter of this species was in Nagliai, in dune habitat, whereas the smallest average diameter of generative adults was in Preila, in dune pine wood habitat. It should be noted that in the habitat with very similar cover of all vegetation layers in Didžiasalis (Table 2), the stem diameter was statistically significantly larger than in Preila (Table 6). However, the average age of generative adults in Didžiasalis was statistically significantly larger than in Preila (Table 4). Stem diameter of vegetative adults was less variable than that of generative adults (Table 6). Thinnest stems were recorded in Galvydiške population, which was characterized by soil disturbance and high percentage of vegetative adults (Table 4). Even less variable was stem diameter of juveniles (Table 6). Therefore, the stem diameter could be used as a reliable additional feature for identification of the juvenile life stage for $C$. scoparius individuals.

The results of this study revealed that density of individuals varied at different sites; however, individuals of all life stages and different age were present in the studied populations. Individuals of $C$. scoparius reach generative stage on the third or fourth year of growth; however, the life span of individual shrubs is quite short. Nevertheless, considering high seed production and persistence of the soil seed-bank (BosSARD, 1990, 1993; Downey \& SMith, 2000; Paynter et al., 2003; TrAn et al., 2016), individuals produce sufficient amounts of seeds during relatively short life to ensure stability of the established population and further invasion into neighbour habitats. Control and eradication of C. scoparius populations should be implemented first in the protected areas and the habitats of the highest conservation value.

\section{REFERENCES}

Abromeit J., Neuhoff W., Steffen H., 1903: Flora von Ost- und Westpreussen, 2. - Berlin.

Bossard C.C., 1990: Tracing of ant-dispersed seeds: a new technique. - Ecology, 71: 2370-2371.

Bossard C.C., 1993: Seed germination in the exotic shrub Cytisus scoparius (Scotch broom) in California. - Madrono, 40: 47-61. 
Cedro A., Bosiacka B., Myśliwy M., 2013: Dendrochronological analysis of three pine species used as a pioneer species to stabilize the coastal dunes of the Southern Baltic coast. - Baltic Forestry, 19(2): 226-235.

Davies C.E., Moss D., Hill M.O., 2004: EUNIS Habitat Classification. Revised 2004. - European Environment Agency European Topic Centre on Nature Protection and Biodiversity.

Dodet M., Collet C., 2012: When should exotic forest plantation tree species be considered as an invasive threat and how should we treat them? Biological Invasions, 14: 1765-1778.

Downey P.O., Sмith J.M.B., 2000: Demography of the invasive shrub Scotch broom (Cytisus scoparius) at Barrington Tops, New South Wales: insights for management. - Australian Ecology, 25: 477-485.

European ENVIRonment Agency, 2017: EUNIS Habitat Classification. - https://www.eea.europa.eu/ data-and-maps/data/eunis-habitat-classification.

Frodin D.G., Heywood V.H., 1968: Cytisus L. - In: Tutin T.G., Heywood V.H., Burges N.A., Moore D.M., Valentine D.H., Walters S.M., WebB D.A. (eds), Flora Europaea, 2: 86-90. - Cambridge.

Gavrilova Ģ., Šulcs V., 1999: Flora of Latvian Vascular Plants. List of Taxa. - Rīga.

GuDŽINSKAS Z., 1999: Conspectus of alien plant species of Lithuania. 10. Fabaceae. - Botanica Lithuanica, 5(2): 103-114.

GuDŽINSKAS Z., 2018: Additions and corrections to the list of alien plant species of Lithuania. - Botanica, 24(1): 26-36.

GUDŽINSKAS Z., ŽALNERAVIČIUS E., 2016. Principles and measures of conservation of the protected plant species and their habitats in south-western Lithuania and recommendations for their implementation. - In: Conservation of Botanical Diversity in south-western Lithuania: 214-221. - Vilnius.

GuDŽInSKas Z., ŽalnERAviČIUS E., 2017: Invaziniai augalai. - In.: BalČIAUSKAS L., ButKus R., Dagys M., GudžInskas Z., Šidagyté E., VaITONIS G., Virbickas T., ŽalneravičIUs E. Invazinès rūšys Lietuvoje: 27-44. - Vilnius.

Gudžinskas Z., Kazlauskas M., Pilate D., Balalaikins M., Pilats M., Šaulys A., Šauliené I., ŠuKIENĖ L., 2014: Lietuvos ir Latvijos pasienio regiono invaziniai organizmai. - Vilnius.
Gudžinskas Z., Petrulaitis L., Žalneravičius E., 2017: New woody alien plant species recorded in Lithuania. - Botanica Lithuanica, 23(2): 153168.

Gudžinskas Z., Petrulaitis L., Žalneravičius E., 2020: Emerging threat of liana Celastrus orbiculatus (Celastraceae) invasion in Europe. - NeoBiota, 00: 000-000.

Hammer Ø., Harper D.A.T, Ryan P.D., 2001: PAST: Paleontological statistics software package for education and data analysis. - Palaeontologia Electronica, 4: 1-9.

ISAACSON D.L., 2000: Impacts of broom (Cytisus scoparius) in western North America. - Plant Protection Quarterly, 15(4):145-148.

León Cordero R., Torchelsen F.P., Anand M., 2016: Cytisus scoparius (Fam. Fabaceae) in southern Brazil - first step of an invasion process? - Anais da Academia Brasileira de Ciencia, 88(1): 149-154.

Мватна P.M., 2016: Scotch broom (Cytisus scoparius (L.) Link) and gorse (Ulex europaeus L.) in South Africa: An assessment of invasiveness, management options and feasibility for countrywide eradication. - Westville.

Mestre L., Chartier M., Renison D., 2014: Effect of livestock on the growth of Rosa rubiginosa in a mountain range: a dendrochronological approach. - Applied Ecology and Environmental Research, 12(4): 855-866.

Mkhize V.S., Mhlambi N., Nanni I., 2013. Scotch broom (Cytisus scoparius), a horticultural escapee targeted for eradication in South Africa. - South African Journal of Botany, 86: 178-178.

Muir L.J., VAmosi J.C., 2015: Invasive Scotch broom (Cytisus scoparius, Fabaceae) and the pollination success of three Garry oak-associated plant species. - Biological Invasions 17(8): 2429-2446.

Oneto S.R., Kyser G.B., DiTomaso J.M., 2010: Efficacy of mechanical and herbicide control methods for Scotch broom (Cytisus scoparius) and cost analysis of chemical control options. - Invasive Plant Science and Management, 3: 421-428.

Parker I.M., Engel A., Haubensak K.A., Goodell K., 2002: Pollination of Cytisus scoparius (Fabaceae) and Genista monspessulana (Fabaceae), two invasive shrubs in California. - Madrono, 49(1): $25-32$. 
Paynter Q., Downey P.O., Sheppard A.W., 2003: Age structure and growth of the woody legume weed Cytisus scoparius in native and exotic habitats: Implications for control. - Journal of Applied Ecology, 40: 470-480.

Paynter Q., Fowler S.V., Memmott J., Shaw R.H., Sheppard A.W., 2000: Determinants of broom (Cytisus scoparius) (L.) Link) abundance in Europe. - Plant Protection Quarterly, 15: 149-155.

Potter K.J.B., Kriticos D.J., Watt M.S., Leriche A., 2009: The current and future potential distribution of Cytisus scoparius: a weed of pastoral systems, natural ecosystems and plantation forestry. Weed Research, 49: 271-282.

Ramula S., Knight T.M., Burns J.H., Buckley Y.M., 2008: General guidelines for invasive plant management based on comparative demography of invasive and native plant populations. - Journal of Applied Ecology, 45: 1124-1133.

Rees M., Paynter Q., 1997: Biological control of Scotch broom: modelling the determinants of abundance and the potential impact of introduced insect herbivores. - Journal of Applied Ecology, 34: 1203-1221.

Rehschun R., Mette T., Menzel A., Buras A., 2017: Soil properties affect the drought susceptibility of Norway spruce. - Dendrochronologia, 45: 81-89. https://doi.org/10.1016/j.dendro.2017. 07.003.

REJMÁNEK M., 2014: Invasive trees and shrubs: where do they come from and what we should expect in the future? - Biological Invasions, 16: 483-498.

Rojas-Badilla M., Le Quesne C., Álvarez C., Velásquez-Álvarez G., Rozas V., 2017: Crecimiento radial de la especie endémica Nothomyrcia fernandeziana (Hook. \& Arn.) Kausel y la invasora Aristotelia chilensis (Molina) Stuntz en la isla Robinson Crusoe, Archipiélago de Juan Fernández, Chile. - Gayana Botany, 74(1): 111-119.

SaKai A.K., Allendorf F.W., Holt J.S., Lodge D.M., Molofsky J., With K.A., Baughman S., CAbin R.J., Cohen J.E., Ellstrand N.C., McCauLey D.E., O’Neil P., Parker I.M., Thompson J.N.,
WeLLER S.G., 2001: The population biology of invasive species. - Annual Review of Ecology and Systematics, 32: 305-32.

Sarateanu V., Durau C.C., Cotuna O., RechiTEAN D., 2017: Incidence of invasive native and non-native species in permanent grasslands from Western Romanian Carpathians. - In: 17th International Multidisciplinary Scientific GeoConference: 591-596. - Sofia.

Sмith J.M.B., 2000: An introduction to the biogeography and ecology of broom (Cytisus scoparius) in Australia. - Plant Protection Quarterly, 15: 140-144.

Srinivasan M.P., Shenoy K., Gleeson S.K., 2007: Population structure of Scotch broom (Cytisus scoparius) and its invasion impacts on the resident plant community in the grasslands of Nilgiris, India. - Current Science, 93(8): 1108-1113.

Srinivasan M.P., Kalita R., Gurung I.K., Bhattacharjee S.K., Predit M.A., Krishnan S., GleeSON S.K., 2011: Seedling germination success and survival of the invasive shrub Scotch broom (Cytisus scoparius) in response to fire and experimental clipping in the montane grasslands of the Nilgiris, South India. - Acta Oecologica, 38(1): 41-48.

Stancevičius A., 1971: Genistaeae Broom. - In: NatkeviČaité-IvanauskienĖ M. (red.), Lietuvos TSR flora, 4: 341-357. - Vilnius.

SuZUKi N., 2000: Pollinator limitation and resource limitation of seed production in the Scotch broom, Cytisus scoparius (Leguminosae). - Plant Species Biology, 15: 187-193.

Tran H., Harrington K.C., Robertson A.W., Watт M.S., 2016: Assessment of herbicides for selectively controlling broom (Cytisus scoparius) growing with radiata pine (Pinus radiata) in New Zealand. - New Zealand Journal of Forestry Science, 46: 13. DOI: 10.1186/s40490-016-0069-8.

Williams P.A., 1981: Aspects of the ecology of broom (Cytisus scoparius) in Canterbury, New Zealand. - New Zealand Journal of Botany, 19: 31-43. 


\title{
INVAZINIO KRŪMO CYTISUS SCOPARIUS (FABACEAE) BRANDOS GRUPĖS IR POPU- LIACIJŲ DEMOGRAFINĖ SUDE்TIS LIETUVOJE
}

\author{
Laurynas TAURA, Zigmantas GUDžInSKAS
}

\section{Santrauka}

Dauguma Lietuvoje esančių svetimžemių invaziniu rūšiu yra kilusios iš kitų žemynų, tačiau Cytisus scoparius yra kilęs iš Vakarų ir Vidurio Europos. Kadangi rūšis sparčiai plinta Lietuvoje ir užima didelius miškų, pajūrio ir žemyninių smèlynų plotus, èmèmès tirti šio augalo populiacijų sudètį.

Šio tyrimo tikslas buvo ivertinti individų tankumą, amžių, brandos grupes ir nustatyti jų ryši su augalo aukščiu ir stiebo skersmeniu. Iš viso buvo ištirtos penkios populiacijos. Tyrimai vykdyti 2017 m. liepos ir rugpjūčio mènesiais šiaurès, pietų ir rytų Lietuvoje. Tyrimui buvo pasirinktos vietos, kuriose Cytisus scoparius augalai užèmé bent 0,1 ha plotą. Tyrimas buvo atliktas taikant tiriamujų laukelių metodą. Kiekvienoje tiriamojoje populiacijoje ištirta ne mažiau kaip po 100 individų, neịskaičiuojant daigų. Iš viso buvo ištirti 583 individai.

Individų tankumo vidurkis tirtose populiacijose buvo nuo 5,15 individų / $\mathrm{m}^{2}$ iki 15,40 individų / $\mathrm{m}^{2}$.
Juveniliniai augalai pasiekia subrendusių vegetatyvinių individų stadiją po antrojo arba trečiojo vegetacijos sezono. Pasitaikè atvejų, kai juveniliniai augalai generatyviniais individais tapo trečiaisiais metais. Juvenilinių individų amžiaus vidurkis buvo 1,10 metų, vegetatyvinių - 2,99 metų, o generatyvinių - 6,26 metų. Seniausias generatyvinis individas buvo 28 metų amžiaus. Linijinès regresijos analizè tarp augalo aukščio ir amžiaus paaiškina 47,4 \% amžiaus variacijos, o stiebo skersmuo paaiškina $81,0 \%$ individo amžiaus variacijos.

Nustatème, kad Cytisus scoparius įvairių brandos grupių individų tankumas pažeistose ir nepažeistose buveinèse yra pakankamai didelis, kad užtikrintu populiacijų ilgaamžiškumą ir tolesni plitimą. Todèl siekiant sumažinti neigiamą invazinès rūšies poveiki biologinei įvairovei, būtina imtis tinkamų populiacijų kontrolès ir naikinimo priemonių. Pirmiausia jos turètų būti taikomos saugomose teritorijose ir didelę gamtosauginę vertę turinčiose buveinèse. 